\begin{tabular}{|c|c|c|}
\hline Tarih Okulu Dergisi (TOD) & \multicolumn{2}{|r|}{ Journal of History School (JOHS) } \\
\hline \multicolumn{3}{|c|}{$(2022), 15(56), 528-541$} \\
\hline Özgünlük kontrolü & intihal.net & Authenticity process \\
\hline \multicolumn{3}{|c|}{ DOI No: http://dx.doi.org/10.29228/Joh.55628 } \\
\hline Makale türü: Araştırma makalesi & & Article type: Research article \\
\hline Geliş tarihi & 25.12 .2021 & Submitted date \\
\hline Kabul tarihi & 11.02.2022 & Accepted date \\
\hline Elektronik yayın tarihi & 28.02 .2022 & Online publishing date \\
\hline
\end{tabular}

Atıf Bilgisi / Reference Information

Sandikci, M.B. \& Onen, C. (2022). Analyzing the Physical Activity of the Elderly Hospitalized in Orthopedic Services According to Their Socioeconomic and İnjury. Journal of History School, 56, 528-541.

\title{
ANALYZING THE PHYSICAL ACTIVITY OF THE ELDERLY HOSPITALIZED IN ORTHOPEDIC SERVICES ACCORDING TO THEIR SOCIOECONOMIC AND INJURY ${ }^{1}$ Muhammed Bahadır SANDIKÇI ${ }^{2} \&$ Cihan ÖNEN ${ }^{3}$
}

\begin{abstract}
This study was performed in order to analyze the physical activity of the elderly hospitalized in orthopedic services of hospitals according to their socioeconomic status and injury history. The scope of this cross-sectional study consists of 105 patients hospitalized in the orthopedic services. A 25-question Questionnaire Form and Physical Activity Scale for the Elderly (PASE) were used for data evaluation. Significantly lower physical activity scores were determined in women with low income, those who regularly pray, being over 75 years old and being illiterate, those who do not live in qualified houses, and whose marital status is widowed or divorced. $62 \%$ of the elderly fell at least once within a year, and the majority of these falls resulted in injury. The average physical activity score of the elderly who have participated in the study is 99.61. Negative changes in socioeconomic variables may negatively affect the physical activity of the elderly. It has been determined in this study that the elderly with low socioeconomic status do less physical activity, and these elderly people have experienced more falls and fall-related injuries. In addition to all these negative aspects, elderly people with low socioeconomic status are hospitalized in orthopedic services mostly due to the injuries caused by falling
\end{abstract}

\footnotetext{
${ }^{1}$ Makale yazımı yazar etki oranı: 1.yazar: \%55, 2. yazar: \%45. Ethical approval was obtained with the decision of Bitlis Eren University Ethical Principles and Ethics Committee dated 07 March 2019 and numbered 2019/03-XXI-XXII.

${ }^{2}$ Dr.Öğr.Ü., Munzur Üniversitesi Spor Bilimleri Fakültesi Beden Eğitimi ve Spor Bölümü, Beden Eğitimi ve Spor Anabilim Dalı, mbsandikci@ munzur.edu.tr, Orcid: 0000-0001-9724-0438

3 Dr.Öğr.Ü., Bitlis Eren Üniversitesi Sağllk Bilimleri Fakültesi Hemşirelik Bölümü, cihan_nen@yahoo.com, Orcid: 0000-0002-9159-7396
} 
Analyzing The Physical Activity of The Elderly Hospitalızed in Orthopedic Services...

and thus, their physical limitations increase and this can further reduce their physical activities. The fact that those doing physical activity with the recommendation of a specialist and those who know the importance of physical activity have fewer falling and injury history emphasizes the importance of doing physical activity consciously. Physical activity awareness of the elderly at all ages, especially those with low socioeconomic status, should be increased. This study has revealed that the physical activity scores of the elderly are low. Hospitalization of the elderly in the orthopedic services following injury may increase their physical activity limitation Appropriate active and passive exercises should be taught according to the condition of the elderly and these exercises should be performed with the support of a health worker when needed.

Keywords: Physical Activity, Elderly, Socioeconomic, Injury, Fall, Orthopedic Services

\section{Ortopedi Servisinde Yatan Yaşlıların Sosyoekonomik ve Yaralanma Durumlarına Göre Fiziksel Aktivitelerinin Değerlendirilmesi}

\section{$\ddot{\mathbf{O z}}$}

$\mathrm{Bu}$ çalışma hastanelerin ortopedi servisinde yatan yaşlıların sosyoekonomik durumları ve yaralanma öykülerine göre fiziksel aktivitelerini değerlendirmek amacıyla yapılmıştır. Kesitsel nitelikteki araştırmanın kapsamını ortopedi servisinde yatan 105 hasta oluşturmaktadır. Veri değerlendirmede 25 soruluk Anket Formu ve Yaşlılar için Fiziksel Aktivite Ölçeği (PASE) kullanılmış̧ır. Kadınların, gelir düzeyi düşük olanların, düzenli ibadet yapanların, 75 yaş üzerinde olanların, okuryazar olmayanların, nitelikli konutlarda oturmayanların ve medeni durumu dul ile boşanmış olanların istatiksel olarak fiziksel aktivite puanları daha düşüktür. Yaşlıların \%62'si yılda en az bir defa düşmüştür ve bu düşmelerin çoğunluğu yaralanma ile sonuçlanmıştır. Çalışmaya katılan yaşlıların fiziksel aktivite puan ortalaması ise 99,61 'dir. Sosyoekonomik değişkenlerdeki olumsuz değişimler yaşlıların fiziksel aktivitesine olumsuz yansıyabilmektedir. Düşük sosyoekonomik özelliğe sahip yaşlıların daha az fiziksel aktivite yaptığı, bu yaşlıların daha fazla düsşme ve düşmeye bağlı yaralanmalarla yüzleștiği bu çalışmada görülmüş̧ür. Bütün bu olumsuzlarla birlikte düşük sosyoekonomik düzeye sahip yaşlılarda düşmeye bağlı meydana gelen yaralanma neticesinde daha fazla ortopedi servisinde yatmaları ve bunun neticesinde fiziki kıstlllıklarının artması fiziksel aktivitelerini daha da azaltabilmektedir. Uzman önerisi ile fiziksel aktivite yapanlar ve fiziksel aktivitenin önemi bilen yaşlıların daha az düşme ile yaralanma öyküsünün olması fiziksel aktivitenin bilinçli yapılmasının önemini öne çıkarmaktadır. Başta düşük soyoekonomik düzeye sahip yaşlılar olmak üzere her yaştaki yaşlıların fiziksel aktivite bilinci artırılmalıdır. Yaşlıların fiziksel aktivite puanının düşük olduğu bu çalışmada görülmüştür. Yaralanma sonrasında ortopedi servisinde yatılması yaşlıların fiziksel aktivite kısıtlığını artırabilmektedir. Yaşlıların durumuna göre uygun aktif ve pasif egzersizler öğretilmeli ve ihtiyaç halinde sağlık çalışanın desteğiyle yürütülmelidir.

Anahtar Kelimeler: Fiziksek Aktivite, Yaşlılar, Sosyoekonomik, Yaralanma, Düşme, Ortopedi Servisi 


\section{INTRODUCTION}

Concerning the change in world population, an increase in the elderly population is observed. While the ratio of the population over 65 years of age to the total population was around 5\% in the 1850 s, today this rate has risen to almost 15\% (Giddens, 2008, p.198-241). An aging society can result in an increase in health problems, deterioration in quality of life and an increase in economic expenditures (Yaman, et al., 2010, p.1-14). It is known that health problems that occur in old age are shaped by the interaction of physical environment and social factors with the role of lifestyle and genetic factors. It is possible that the direct or indirect effects of many, if not all, of these factors can be prevented or positively changed. It is possible for vital problems related to falling to be prevented through the emergency interventions for the elderly (WHO, 2007).

The main problems encountered in old age are listed as physiological changes, decrease in abilities, reduced functionality, emerging chronic diseases, injuries caused by falls and accidents (Akdeniz, et al., 2009, p.7-10). Old age is a period in which disability and trauma may occur along with health problems. Traumas are a serious problem frequently seen in old age and are more severe than in young people. Due to the level of trauma, the injuries that occur in the elderly are more severe (Runciman, et al., 1996, p.711-718). In the United States, 2.2 million non-fatal injuries occurred in the elderly in 2009, and more than 581.000 of those injured individuals were hospitalized. More than 19.000 elderly people died due to falls in the same year (Ambrose, et al., 2013, p.51-61).

According to studies performed, causes and risk factors for falls in the elderly differ. There are findings indicating that sociodemographic factors, advanced age, chronic and acute health problems, dizziness, weakness, physical activity, lower extremity problems, problems in balance, vision loss, gait disturbances, urinary and stool incontinence, and mental problems increase the risk of falling (Yıldırım and Karadakovan, 2004, p.78-83). Vital interventions in elderly people being at risk of falling against these problems are prevention of falls, strengthening of muscle structures, providing balance, regulation of posture, exercise training, elimination of joint movement restriction and improvement of aerobic capacity. For instance, performing balance exercises against falling, which is a very dangerous situation for the elderly, reduces falls by almost $50 \%$ in elderly individuals (Abit Kocaman, et al., 2020, p.11-20). 
Analyzing The Physical Activity of The Elderly Hospitalızed in Orthopedic Services...

\section{METHOD}

\section{Scope of the Research}

The elderly people hospitalized in Bitlis Tatvan State Hospital and Bitlis State Hospital Orthopedic Service between 20.03.2019 and 31.05.2019 constitute the scope of this cross-sectional study. No sampling method was used in the study, and all of the patients were tried to be reached. 105 patients participated in the study, and a total of 95 people were evaluated in the study after excluding 10 questionnaires with missing data.

\section{Data Collection and Evaluation}

In the study, a questionnaire form composed of 25 questions and prepared by the researchers and the Physical Activity Scale for the Elderly (PASE) scale were used in data evaluation. The physical activity of the participants was evaluated with PASE. Turkish Validity and Reliability study of the PASE scale developed by Washburn et al. (Washburn, et al.,1993, p.153-162) in 1993 was performed by Ayvat et al. (Ayvat, et al., 2017, p.) in 2016. PASE covers the leisure time activities, housework activities and work-related activities of the elderly in the last week. There is a PASE Active weight score determined for each different activity performed within a week. In calculating the score of the PASE scale, the activity weights and the activity frequencies are multiplied. As the final calculated score increases, the level of physical activity also increases.

\section{Administrative and Ethical Consent of the Study}

Administrative permission required to collect data from patients hospitalized in the Orthopedic service of hospitals was taken with the decision of Bitlis Provincial Directorate of Health dated 20.03.2019 and numbered 75384813. Ethical approval was obtained with the decision of Bitlis Eren University Ethical Principles and Ethics Committee dated 07 March 2019 and numbered 2019/03-XXI-XXII.

\section{FINDINGS AND INTERPRETATION}

The average age of the people participating in the research is 71.4, and the age range is between 65 and 93. Socio-demographic characteristics and physical activity comparison of the elderly are presented in Table1. 


\section{Table 1}

Socio-demographic Characteristics and Physical Activity Scores of Elderly Inpatients in the Orthopedics Service

\begin{tabular}{|c|c|c|c|c|c|c|c|}
\hline Variables & & $\mathbf{n}$ & $\%$ & Aver ${ }^{a}$ & $\mathbf{S D}^{\mathbf{b}}$ & & $\mathbf{p}$ \\
\hline Gender & Female & 36 & 37.9 & 76.66 & 61.6 & $\mathrm{t}^{\mathrm{c}}=-2.423$ & $0.017^{*}$ \\
\hline & Male & 59 & 62.1 & 113.62 & 77.79 & & \\
\hline Age & $65-69$ & 52 & 54.7 & 127.96 & 72.87 & $\mathrm{f}^{\mathrm{d}}=10.285$ & $\mathrm{p}<$ \\
\hline & $70-74$ & 19 & 20.0 & 72.27 & 61.12 & & $0.001^{*}$ \\
\hline & $\geq 75$ & 24 & 25.3 & 59.83 & 59.82 & & \\
\hline Marital & Widow/Divorced & 29 & 30.5 & 64.35 & 72.99 & $\mathrm{t}=-3.231$ & 0.002 \\
\hline Status & Married & 66 & 69.5 & 115.11 & 69.42 & & \\
\hline Educational & Illiterate & 51 & 53.7 & 75.84 & 60.53 & $\mathrm{t}=-3.578$ & $0.001^{*}$ \\
\hline Background & $\begin{array}{l}\text { Primary/High } \\
\text { School }\end{array}$ & 44 & 46.3 & 127.17 & 79.08 & & \\
\hline Average & $0-1000 \mathrm{TL}^{* *}$ & 30 & 31.6 & 80.18 & 75.99 & $\mathrm{f}=4.005$ & $0.021^{*}$ \\
\hline Monthly & $1000-2000 \mathrm{TL}$ & 55 & 57.9 & 100.28 & 69.73 & & \\
\hline Income & $>2000 \mathrm{TL}$ & 10 & 10.5 & 154.25 & 69.19 & & \\
\hline Source of & Retirement Pension & 28 & 29.5 & 111.51 & 84.94 & $\mathrm{f}=2.371$ & 0.099 \\
\hline Income & $\begin{array}{l}\text { Old-age/Widow's } \\
\text { Pension }\end{array}$ & 37 & 38.9 & 79.24 & 63.04 & & \\
\hline & Other & 30 & 31.6 & 113.62 & 72.22 & & \\
\hline Profession & $\begin{array}{l}\text { Not working, } \\
\text { Retired }\end{array}$ & 37 & 38.9 & 110.15 & 81.64 & $f=2.879$ & 0.061 \\
\hline & Self-employed etc. & 30 & 31.6 & 112.37 & 75.48 & & \\
\hline & Housewife & 28 & 29.5 & 72.02 & 54.06 & & \\
\hline Type of & Detached & 60 & 63.2 & 111.55 & 69.08 & $\mathrm{f}=3.378$ & $0.038^{*}$ \\
\hline House & Apartment & 22 & 23.2 & 93.35 & 88.32 & & \\
\hline & Slams & 13 & 13.6 & 55.09 & 53.05 & & \\
\hline $\begin{array}{l}\text { a } \text {, average; }{ }^{\mathbf{b}} \text {, } \\
\text { Test; }{ }^{*}, \mathrm{p}<0.0\end{array}$ & $\begin{array}{l}\text { tandard deviation; }{ }^{\text {c }} \text {, } \\
{ }^{* *} \text {,Turkish Lira }\end{array}$ & & pende & nt Samp & es t Tes & d, One-W & Anor \\
\hline
\end{tabular}

Considering the physical activity scores of the elderly hospitalized in the orthopedic services according to their socio-demographic characteristics, the physical activity scores of women are significantly lower than men $(\mathrm{p}=0.017)$. There is a significant difference between age and physical activity score. In the Post Hoc analysis Tukey comparison, those aged 65-69 had significantly higher physical activity scores than those aged between 70-74 $(\mathrm{p}=0.008)$ and those aged over 75 ( $p<0.001)$. In addition, there is a moderately significant and negative correlation between the age and physical activity of the elderly hospitalized in the orthopedic services $(r=-0.427 ; \mathrm{p}<0.001)$. Physical activity score of people with such marital status as widow, single and divorced is significantly lower than 
Analyzing The Physical Activity of The Elderly Hospitalızed in Orthopedic Services...

married ones $(\mathrm{p}=0.002)$. In the comparison of educational background, the physical activity score of illiterate students has been found to be significantly lower than primary / high school graduates $(\mathrm{p}=0.001)$. There is a significant difference between the income status of the participants and their physical activities $(\mathrm{p}=0.021)$. Moreover, there is a weakly positive correlation between income status and physical activity scores of the elderly $(\mathrm{r}=0.263 ; \mathrm{p}=0.010)$. Physical activity scores of those with an income up to 1000 Turkish Liras are statistically higher than those with an income above 2000 Turkish Liras ( $\mathrm{p}=0.16)$. Considering the type of house they live in, there is a statistically significant difference between the type of house and the physical activity score $(\mathrm{p}=0.038)$. Those staying in a detached flat have a statistically higher physical activity score than those living in slums $(\mathrm{p}=0.032)$.

Table 2

Physical Activity Scores of the Elderly by Activity

\begin{tabular}{|c|c|c|c|c|c|c|c|}
\hline Activity & & $\mathbf{n}$ & $\%$ & aAver & ${ }^{b}$ SD & $c_{t}$ & $\mathbf{p}$ \\
\hline \multirow{2}{*}{ Staying at Home } & Yes & 76 & 80 & 96.27 & 72.12 & \multirow{2}{*}{-0.878} & \multirow{2}{*}{0.382} \\
\hline & No & 19 & 20 & 112.96 & 81.66 & & \\
\hline \multirow{2}{*}{ Being at the Coffee Shop } & Yes & 37 & 38.9 & 116.39 & 69.3 & \multirow{2}{*}{1.786} & \multirow{2}{*}{0.077} \\
\hline & No & 58 & 61.1 & 88.91 & 75.44 & & \\
\hline \multirow{2}{*}{ Walking } & Yes & 47 & 49.5 & 120.9 & 73.08 & \multirow{2}{*}{2.882} & \multirow{2}{*}{$0.005 *$} \\
\hline & No & 48 & 50.5 & 78.76 & 69.43 & & \\
\hline \multirow{2}{*}{ Reading Book } & Yes & 4 & 4.2 & 127.13 & 60.31 & \multirow{2}{*}{0.758} & \multirow{2}{*}{0.450} \\
\hline & No & 91 & 95.8 & 98.4 & 74.56 & & \\
\hline \multirow{2}{*}{ Doing Sports } & Yes & 5 & 5.3 & 177.91 & 87.99 & \multirow{2}{*}{2.499} & \multirow{2}{*}{$0.014 *$} \\
\hline & No & 90 & 94.7 & 95.26 & 71.19 & & \\
\hline \multirow{2}{*}{ Being Engaged in Hobbies } & Yes & 32 & 33.7 & 101.63 & 83.98 & \multirow{2}{*}{0.189} & \multirow{2}{*}{0.851} \\
\hline & No & 63 & 66.3 & 98.59 & 69.04 & & \\
\hline \multirow{2}{*}{ Praying } & Yes & 76 & 80 & 108.81 & 72.68 & \multirow{2}{*}{2.491} & \multirow{2}{*}{$0.015^{*}$} \\
\hline & No & 19 & 20 & 62.81 & 69.14 & & \\
\hline
\end{tabular}

a, average; ${ }^{\text {b }}$, Standard deviation; ${ }^{\mathrm{c}}$, Independent Samples t Test; ${ }^{\text {, }} \mathrm{p}<0.05$

Considering the physical activities of the elderly hospitalized in the orthopedic services, the physical activity score of those reading books is higher than those who do not. However, there is no statistical difference between their scores $(\mathrm{p}=0.450)$. The physical activity scores of those who walk $(\mathrm{p}=0.005)$ and those who do sports $(\mathrm{p}=0.014)$ are statistically significantly higher than those who do not. The physical activity score was found to be significantly higher in the patients who pray (0.015). 


\section{Table 3}

Physical Activity Scores of The Participants by Their Physical Activity History, Fall and İnjury Status

\begin{tabular}{lccccccc}
\hline Variables & & $\mathbf{n}$ & $\mathbf{\%}$ & ${ }^{\mathbf{a}}$ Aver & ${ }^{\mathbf{b}} \mathbf{S D}$ & $\mathbf{c}^{\mathbf{t}}$ & $\mathbf{p}$ \\
\hline Doing Physical Activity with & Yes & 24 & 25.3 & 112.24 & 68.49 & 0.967 & 0.336 \\
the Recommendation of a & No & 71 & 74.7 & 95.34 & 75.72 & & \\
Specialist & & & & & & & \\
Knowing the Importance of & Yes & 69 & 72.6 & 104.85 & 71.77 & 1.125 & 0.263 \\
Physical Activity & No & 26 & 27.4 & 85.72 & 79.29 & & \\
Warm up Before Physical & Yes & 26 & 27.4 & 119.41 & 91.67 & 1.389 & 0.174 \\
Activity & No & 69 & 72.6 & 92.15 & 65.33 & & \\
Falling History & Yes & 59 & 62.1 & 93.33 & 75.48 & - & 0.292 \\
& No & 36 & 37.9 & 109.91 & 71.27 & 1.060 & \\
History of Falling Injury & Yes & 49 & 81.7 & 90.28 & 77.54 & - & 0.867 \\
& No & 11 & 18.3 & 94.55 & 70.48 & 0.168 & \\
Injury from Physical Activity & Yes & 30 & 53.6 & 96.42 & 76.34 & 0.258 & 0.797 \\
& No & 26 & 46.4 & 91.09 & 73.41 & & \\
\hline
\end{tabular}

a , average; ${ }^{\mathrm{b}}$, Standard deviation; ${ }^{\mathrm{c}}$, Independent Samples t Test

Among those hospitalized in the orthopedic services, the physical activity score of those who know the importance of physical activity, those who do physical activity with the recommendation of a specialist, and those who warm up before doing physical activity. But there is no statistically significant relationship is higher. However, there is no statistically significant correlation ( $>0.05$ ). In addition, physical activity scores are higher in those who have no history of falling and those who are not injured by falling.

Table 4

Average Physical Activity Scores of the Participants

\begin{tabular}{ccccc}
\hline $\mathrm{n}$ & Average & Minimum & Maximum & Standard Deviation \\
\hline 95 & 99.61 & 0.00 & 319.82 & 73.97 \\
\hline
\end{tabular}

The physical activity score average of the participants is 99.61 . The physical activity score of the elderly varies between 0 and 319 .

\section{DISCUSSION, CONCLUSION AND RECOMMENDATIONS}

The physical activity score of men hospitalized in the orthopedic services is significantly higher than women. Physical activity has a significant place in 
protecting and improving women's health. It was observed in a study based on the follow-up of women aged 55-69 for seven years that moderate physical activity was found to reduce the incidence of cardiovascular and respiratory system diseases. Moreover, it was ascertained that moderate physical activities for 30 minutes a day would reduce lean tissue loss in the elderly, increase bone mineral density, and provide protection against different chronic diseases such as osteoporosis (Ersoy and Akbulut, 2006, p.41-51). In university students, physical activity status is closer to each gender. $32 \%$ of male students and $47 \%$ of female students are physically inactive (Haase, et al.,2004, p.182-190). The reason for a decrease in physical activity scores of women can be the majority of women being housewives, the majority of them not working, doing less warm-up exercises before starting physical activity, fewer people knowing the importance of physical activity, walking less than men, existence of more elderly women, and none of the women doing sports. Moreover, it has been observed in this study that the history of falls resulting in injury is higher in women. Accordingly, the fact that women have a history of staying in orthopedic service longer with a physical limitation may have decreased their physical activity scores (Güneytepe, et al., 2008, p.15-19). Elderly women must continue physical activity in order to increase their quality of life. Physical activity should be chosen appropriately for older women (Belice, et al., 2021, p.44-48). In one study, fall-related injuries were considered to rank first in the traumatic histories of the elderly over the age of 75. The most common post-traumatic injuries in this age group are head and extremity injuries. The effect of traumas in the elderly population is more severe than the younger population due to the conditions like osteoporosis, etc. (Güneytepe, et al., 2008, p.15-19). There is a moderately significant and negative correlation between the age and physical activity of the elderly hospitalized in the orthopedic service. As age increases, physical activity decreases. It may be due to the increase in physical activity limitation as the age progresses, the older age group to have a history of falling more frequently, their inability to maintain their own self-care, and the higher incidence of falls resulting in injury in the elderly. In this study, up to $62 \%$ of the elderly fell at least once within a year. It was ascertained in another study that approximately $30 \%$ of the elderly population over the age of 65 experienced at least one fall within a year (Chien and Guo, 2014). Physical activity score is higher for those who know the importance of physical activity and hospitalized in the orthopedic service, those who do physical activity with the recommendation of a specialist, and those who warm up before doing physical activity. In addition, physical activity scores are higher in those who do not have a history of falling and those who are not injured by falling. Higher physical activity scores of individuals without a history of falling that resulted in injury may be due to the fact that they know the importance of physical 
activity, perform physical activity with the recommendation of a specialist, and they warm up before doing advanced physical activity.

The physical activity score of illiterate inpatients in the orthopedic service is significantly lower than primary / high school graduates. In our study, the physical activity score of those who read books is also higher than those who do not. The fact that the income and education levels of those who read books were higher than those who did not read may have increased their physical activity scores. Looking at the literature study on the related subject, it was observed that elderly women aged 75 and over fell more than elderly men, and illiterate people fell more than literate individuals. It is also known that women have a higher rate of falling than men. There are also findings indicating that advanced age and unmarried people are at higher risk of falling (Kibar, et al. 2015, p.15). In the orthopedic service study, the physical activity score of the widow, single and divorced people was significantly lower than the married individuals. The possible reasons for a decrease in their physical activity score could be being a widow and divorced individual at a higher rate among housewives, living in slums with worse physical conditions, and widowed participants were mostly 75 years old and over. Physical activity scores may have decreased due to the fact that illiterate elderly people had more falls resulting in injury, more people were in unemployment, less people knew the importance of physical activity, and fewer people did physical activity with the recommendation of a specialist. Furthermore, illiterate people are more common in the elderly population.

There is a significant difference between the income status of the participants and their physical activities. In addition, there is a weakly positive correlation between income status and physical activity scores of the elderly. Physical activity scores of those with an income up to 1000 Turkish Liras are statistically higher than those with an income above 2000 Turkish Liras. In a study conducted in England in 2002, significant correlations were established between family income of individuals and their conscious participation in sports activities (Korkmaz and Deniz, 2013, p.46-56). The low social and educational indicators of the elderly with low income may also have affected their physical activity status.

From the research group, those who live in a detached flat have a statistically higher physical activity score than those living in slums. In a different study conducted on elderly, some findings were obtained indicating that the majority of elderly people living alone were women and men had better incomes (Ayranc1, et al. 2005, p.113-119). The fact that those living in slums had a lower 
Analyzing The Physical Activity of The Elderly Hospitalızed in Orthopedic Services...

socioeconomic and educational status, knew less about the importance of physical activity, and did not do physical activity with the recommendation of a specialist may have decreased their physical activity scores.

The physical activity score of the elderly, hospitalized in orthopedic service, who walk and do sports are significantly higher than those who do not. As shown in the studies on the elderly, it has been determined that aerobic exercise training is associated with the risk of falling and known cognitive functions are affected. It has been observed that doing exercises for 8 weeks with square stepping exercise in elderly individuals positively affects their cognitive functions. Square stepping exercise training has also been found to have positive effects on gait performance in the elderly (Abit Kocaman, et al., 2020, p.11-20). Self-employed individuals, farmers, those with better educational background and those with higher incomes take more walks. It is seen that the individuals who do sports are public pensioners and people with high education and income. The fact that sports is a more advanced physical activity than walking and that those who do sports are more active by taking care of themselves may have contributed to a significant increase in the physical activity score.

Among the patients hospitalized in the orthopedic service, the physical activity scores of the worshipers are significantly higher than those who do not pray regularly. Worships such as prayer and ablution make people move. Even if people are orthopedic patients, they can make alternative movements of worship according to current situations. Patients who adhere to their religious rituals may force the conditions to fulfill their prayers.

The average score of the participant elderly individuals is 99.61. The low physical activity score of the elderly participating in the study may have been caused by the restriction of their physical activities as a result of their injuries, staying in the orthopedic service and being at an advanced age. This can also increase the likelihood of them falling and being injured (Gillespie, et al., 2003). For instance, the elderly who have clinical foot problems face a greater risk of loss of balance and falling (Şavkın, et al., 2021, p. 279-283). Providing training programs (balance-walking, hearing), muscle strengthening and resistance exercises to individuals at risk of falling are among the preventive measures (Gillespie, et al., 2003). Another preventive measure is to evaluate the fall risks of the elderly with appropriate assessment methods (Altunkaya, 2020, p.367373). Moreover, identifying and intervening the underlying causes of falls can reduce the risk of recurrent falls (Güneş Gencer, et al., 2021, p.70-83).

In conclusion, it has been determined in this study that the elderly with low socioeconomic characteristics do less physical activity. These elderly people 
have more falls and a history of fall-related injuries. Older people with lower socioeconomic status are hospitalized more in orthopedic services as a result of fall-related injuries. As a result, the increase in their physical limitations can further reduce their physical activities.

The fact that those who do physical activity with the recommendation of a specialist and the elderly who know the importance of physical activity have less history of falling and injury highlights the importance of doing physical activity consciously. Physical activity awareness of the elderly at all ages, especially those with low socio-economic status, should be increased. It has been observed in this study that the physical activity scores of the elderly are low. Hospitalization in the orthopedic service following an injury may increase the physical activity limitation of the elderly. According to the situation of the elderly in the orthopedic service, active and passive exercises should be taught to them and the support of the health worker should be provided if needed.

The scope of this study consists of two state hospitals located within the borders of Bitlis province. The number of participants was limited to 95 since people over the age of 65 who were hospitalized in the orthopedic service were examined.

\section{REFERENCES}

Akdeniz, M., Yaman, A., Tufan, İ. \& Yaman, H. (2009). Old age and disability. STED, 18 (5), VII-X.

Altunkaya, S. (2020). Evaluation of time domain features of the acceleration signals recorded during the walk to determine the risk of falling in the elderly. European Journal of Science and Technology, 20, 367-373. https://doi.org/10.31590/ejosat.748156.

Ambrose, A. F., Paul G., \& Hausdorff J. M. (2013). Risk factors for falls among older adults: A review of the literature. Maturitas, 75(1), 51-61. https://doi.org/10.1016/j.maturitas.2013.02.009.

Ayranc1, Ü., Köşgeroğlu, N., Yenilmez, Ç. \& Aksoy, F. (2005). Socioeconomic characteristics and health status of the elderly in Eskişehir. STED, 14(5), 113-9.

Ayvat, E., Kilinç, M. \& Kirdi, N. (2017). The Turkish version of the physical activity scale for the elderly (PASE): its cultural adaptation, validation, and reliability. Turk J Med Sci., 47(3), 908-915. https://doi.org/10.3906/sag1605-7. 
Analyzing The Physical Activity of The Elderly Hospitalızed in Orthopedic Services...

Belice, T., Bölükbaşı, S. \& Mandıracıoğlu A. (2021). Physical ınactivity effects on quality of life in the elderly. $C B U-S B E D, 8(1), 44-48$.

Chien, MH. \& Guo, HR. (2014). Nutritional status and falls in communitydwelling older people: A longitudinal study of a population-based random sample. PLoS ONE, 9(3), e91044. https://doi.org/10.1371/journal. pone.0091044.

Ersoy, G. \& Akbulut, G. Ç. (2006). The evaluation of the nutrition and the physical activity levels of the elderly people (65 years old) living in different socio-economic Ievels. J Nutr and Die, 34(1), 41-51.

Haase, A., Steptoe, A., Sallis, J.F. \& Wardle, J. (2004). Leisure-time physical activity in university students from 23 countries: associations with health beliefs, risk awareness and national economic development. Preventive Medicine, 39, 182-190.

Gillespie, LD., Gillespie, WJ., Robertson, MC., Lamb, E., Cumming, RG. \& Rowe, BH. (2003). Interventions for preventing falls in elderly people. Cochrane Database Syst Rev., 4, CD000340.

Güneş Gencer, G Y., İpek, L., Kara, D S., Uzun, F. \& Çetin, S Y. (2021). Investigation of studies on falling and balance in the elderly in Turkey. Elderly Issues Research Journal (EIRJ), 14(2), 70-83. https://doi.org/ 10.46414/yasad.1035803.

Güneytepe, Ü. İ., Aydın, Ş. A., Gökgöz, Ş., Özgüç, H., Ocakoğlu, G. \& Aktaş, H. (2008). The factors influencing the mortality in elderly trauma patients and scoring systems. Journal of Uludağ University Medical Faculty, 34(1), $15-19$.

Giddens A. (2008). Sociology in Socialization, the Flow of Life and Aging, (198241), (trnslt. H. Özel), Red Publications.

Kibar, E., Aslan, D., Karakoç, Y. \& Kutsal, Y. G. (2015). Frequency, risk factors and preventive approach to fall among aged population living in a nursing home in Ankara. TAF Preventive Medicine Bulletin, 14(1), p23-32.

Kocaman, A., Kırdı, N., Aksoy, S., Elmas, Ö., \& Balam Yavuz, B. (2020). The effect of square-step exercise training on postural control, cognitive function and gait in elderly: Pilot study. Turk J Physiother Rehabil, 31(1), 11-20. https://doi.org/10.21653/tjpr.523616. 
Korkmaz, N. H. \& Deniz, M. (2013). A research on the relationship between the level of physical activity and socio-economic status in adults. Sport Sciences, 8(3), 46-56.

Runciman, P., Currie, CT. \& Nicol M. (1996). Discharge of elderly people from an accident and emergency department: Evaluation of health visitor follow-up. J Adv Nurs., 24, 711-718.

Şavkın, R., Bayrak, G. \& Büker, N. (2021). Balance, falls, fear of falling, and foot function in elderly people in community-dwelling older adults. Acıbadem University Health Sciences Journal (AUHSJ), 12(2), 279-283. https://doi.org/10.31067/acusaglik.847281.

Yıldırım, Y. K. \& Karadakovan, A. (2004). The relationship between fear of falling, activities of daily living and quality of life among elderly individuals. Turkish Journal of Geriatrics, 7(2), 78-83.

Yaman, H., Akdeniz, M. \& Howe, J. (2010). GeroFam Concept: a Proposal of Solution for the Coming Demographic Change. Gero Fam, 4(1), 1-14.

World Health Organisation. (WHO). (2007). Global report on falls prevention in older age. WHO Library Cataloguing in Publication Data. www.who.int/ ageing/Project, Access date: 16.10.2021

Washburn, R.A., Smith, K.W., Jette, A.M. \& Janney C.A. (1993). The physical activity scale for the elderly (pase): development and evaluation. Journal of Clinical Epidemiology, 46 (2), 153-162.

\section{EXTENDED ABSTRACT}

It is known that health problems that occur in old age are shaped by the interaction of physical environment and social factors with the role of lifestyle and genetic factors. It is possible that the direct or indirect effects of many, if not all, of these factors can be prevented or positively changed. This study was performed in order to analyze the physical activity of the elderly hospitalized in orthopedic services of hospitals according to their socioeconomic status and injury history. The elderly people hospitalized in Bitlis Tatvan State Hospital and Bitlis State Hospital Orthopedic Service between 20.03.2019 and 31.05.2019 constitute the scope of this cross-sectional study. No sampling method was used in the study, and all of the patients were tried to be reached. 105 patients participated in the study and a total of 95 people were evaluated in the study after excluding 10 questionnaires with missing data. A 25-question Questionnaire Form and Physical Activity Scale for the Elderly (PASE) were used for data evaluation. 
PASE covers the leisure time activities, housework activities and work-related activities of the elderly in the last week. There is a PASE Active weight score determined for each different activity performed within a week. In calculating the score of the PASE scale, the activity weights and the activity frequencies are multiplied. As the final calculated score increases, the level of physical activity also increases. Physical activity scores of women, those with low income, those who regularly pray, being over 75 years old and being illiterate, those who do not live in qualified houses, and whose marital status is widow or divorced, are significantly lower. $62 \%$ of the elderly fell at least once within a year, and the majority of these falls resulted in injury. The average physical activity score of the elderly who have participated in the study is 99.61. Negative changes in socioeconomic variables may negatively affect the physical activity of the elderly. It has been determined in this study that the elderly with low socioeconomic status do less physical activity, and these elderly people have experienced more falls and fall-related injuries. In addition to all these negative aspects, elderly people with low socioeconomic status are hospitalized in orthopedic services more as a result of injuries caused by falling and thus, their physical limitations increase and this can further reduce their physical activities. The fact that those doing physical activity with the recommendation of a specialist and those who know the importance of physical activity have fewer falling and injury history emphasizes the importance of doing physical activity consciously. Physical activity awareness of the elderly at all ages, especially those with low socioeconomic status, should be increased. This study has revealed that the physical activity scores of the elderly are low. Hospitalization of the elderly in the orthopedic services following injury may increase their physical activity limitation Appropriate active and passive exercises should be taught according to the condition of the elderly and these exercises should be performed with the support of a health worker when needed. The fact that those who do physical activity with the recommendation of a specialist and the elderly who know the importance of physical activity have less history of falling and injury highlights the importance of doing physical activity consciously. 